\title{
The benefits to South African investors from international portfolio diversification using an ex ante investment strategy
}

\author{
N. Bhana \\ Graduate School of Business, University of Durban-Westville, Private Bag X54001, Durban, 4000 Republic of South Africa
}

Roceived 30 October 1986; accepted 10 January 1987

\begin{abstract}
This investigation uses an ex ante 'buy the market' investment strategy to compare the risk-return characteristics of a South African portfolio with an internationally diversified portfolio representing 18 countries during the $1969-1983$ period. Without taking differences in risk into consideration, the international portfolio, on average, produced slightly higher annual returns. Furthermore, the South African portfolio produced very erratic returns in comparison with the steady returns attained by the international portfolio. The results also demonstrate the ability of international portfolios to maximize the long-term rate of return, even though many year-by-year returns may be less than the returns from domestic portfolios. The international portfolio has a relative performance which is 3,0387 times that of the South African portfolio when the actual risk associated with the two portfolios are taken into consideration. An international portfolio containing goldmining shares is able to attain relatively high returns without adding to the overall portfolio risk. By contrast a South African investor holding goldmining shares bears a large element of risk which is not diversifiable because of exchange control restrictions. The results of this investigation provide a strong case for international portfolio diversification by South African investors. Furthermore, South African investors are bearing a high cost for the inability to attain effective diversification as a result of exchange control regulations. In view of the public policy implications of foreign security investments, representations should be made to the authorities with the objective of expediting exchange control reform in South Africa.
\end{abstract}

Hierdie ondersoek gebruik 'n ex ante 'koop-die-mark'-belegginstrategie ten einde die risikoopbrengseienskappe van 'n Suid-Afrikaanse portefeulje met 'n internasionaalgediversifiseerde portefeulje verteenwoordigend van 18 lande gedurende die $1969-1983$ periode, te vergelyk. Sonder inagneming van risikoverskille, blyk dit dat die internasionale portefeulje gemiddeld hoër jaarlikse rendemente gehad het. Boonop het die Suid-Afrikaanse portefeulje wisselvallige opbrengste gelewer in vergelyking met die stabiele opbrengste verkry deur die internasionale portefeulje om langtermyn-opbrengskoerse te maksimeer, selfs al blyk jaar-virjaar-opbrengste minder te wees as met huishoudelike portefeuljes. Wanneer die werklike risiko's betrokke in die twee portefeuljes in aanmerking geneem word, was die relatiewe vertoning van die internasionale portefeulje 3,0387 keer die van die Suid-Afrikaanse portefeulje.'n Internasionale portefeulje met goudaandele is in staat tot relatief hoz opbrengste sonder die toevoeging van die algehele portefeuljerisiko's. In teenstelling hiermee, moet die Suid-Afrikaanse belegger 'n redelike groot risiko-element self akkommodeer aangesien wisselkoersbeheerbeperkings diversifikasie uitskakel. Die resultate van hierdie ondersoek verskaf 'n sterk basis vir Suid-Afrikaanse beleggers om betrokke te raak in internasionale portefeuljediversifikasie. As gevolg van wisselkoersbeheermaatreèls, moet die Suid-Afrikaanse belegger ook nog die hoz koste vir die onvermoè om effektiewe diversifikasie te inisieer, absorbeer. In die lig van die openbarebeleid-uitkomste van buitelandse sekuriteitsbeleggings, behoort die owerhede versoek te word om bestaande wisselkoersbeheermaatreeks spoedig in heroorweging te neem.

\section{Introduction}

The importance of diversification for reducing the risk of a portfolio has been adequately documented in investment literature. Following Grubel (1968), much attention has been devoted to empirical studies on international portfolio diversification. The rationale for international portfolio diversification is that foreign securities should be expected to have low covariances with a portfolio of domestic risky assets (Solnik \& Noetzlin, 1982). The market portfolio used in the Capital Asset Pricing Model (CAPM) is theorectically supposed to contain all risky assets available to the investor. Furthermore, almost all empirical studies of the CAPM have used some market index (Standard and Poor's 500 Composite Index, JSE Overall Actuaries Index, etc.) as a surrogate for the market portfolio. This is a gross understatement of the market portfolio because the composite market index only includes securities that are listed on a given stock exchange. Therefore, it can be demonstrated that foreign securities should be included in domestic portfolios. The true market portfolio should be a total-world portfolio to derive maximum benefits from diversification.

\section{The benefits from international portfolio diver- sification using an ex ante strategy}

Various overseas studies have demonstrated the ability of international portfolios to outperform purely domestic portfolios. Because of the existing exchange control regulations very little attention has been paid to the possibility of investing in foreign securities by South African residents. Bhana (1986) has demonstrated that South African investors are also likely to derive substantial benefits by including foreign securities into their portfolios. However, this study allocated funds to the various foreign securities included in optimal international portfolios on the basis of ex post data. This approach allocated investment funds after reviewing the results of a period that had already passed. Such an analysis is not 
likely to be of assistance in making investment decisions for the future. In situations where the investor has no information of future investment returns, it can be expected that he adopts a strategy to 'buy the market'. This strategy implies that the investor would buy all available securities in proportion to their market capitalization. Such a strategy will ensure that the portfolio would be fully diversified. The 'buy the market' approach is an ex ante investment strategy in that it avoids the influence of events that actually occurred during a given period. By spreading the investment funds over the entire market the effect of past events and past performance is avoided.

For analytical purposes, two distinct groups of investors, each having unique investment opportunities available to them will be considered:

(a) A South African investor who is constrained by exchange control regulations to limit investments to securities listed on the JSE (goldmining and industrial shares).

(b)An investor not constrained by exchange control regulations, and is therefore able to acquire securities on the JSE as well as the securities of $\mathbf{1 7}$ foreign countries that are considered for inclusion in the international portfolio.

In using the 'buy the market' approach it would be difficult to determine the proportion of the market capitalization to be invested in the different securities each year. Therefore, it is assumed that each of the above investors would purchase equal Rand amounts in each security group available to them. For instance, a South
African investor not constrained by exchange control would invest equal Rand amounts in goldmining and industrial shares on the JSE as well as in each of the 17 foreign countries.

The risk-return characteristics for each of the above portfolios were calculated during the $1969-1983$ period. Furthermore, the investment characteristics of the two portfolios was plotted on a risk-return diagram for each year, and thereby indicated the respective position of the South African portfolio and the international portfolio for a specific year. Market lines were drawn by joining the South African risk-free rate to the above-mentioned points in each year. The annual returns for each of the two investment strategies as well as the difference between the two strategies was measured from the diagram for both South African market risk as well as the international market risk. The market risks were represented by the standard deviations of the portfolio returns for each year in the two markets under consideration. The relative performance of the two portfolios is presented in Table 1.

The figures in Table 1 indicate that on average, during the 1969 - 1983 period, the ex ante selection procedure would have provided fairly large positive returns. Furthermore, these returns could have been attained at either of the two risk levels under investigation. Investment in a portfolio of South African equity shares would have produced annual returns of $14,15 \%$ and $16,38 \%$ at the international market risk level and South African market risk level respectively. Investment in the international equity portfolio would have produced annual

Table 1 Annual returns for South African and international market portfolios at South African and international market risk levels for the period $1969-1983$.

\begin{tabular}{|c|c|c|c|c|c|c|}
\hline \multirow[b]{3}{*}{ Year } & \multicolumn{3}{|c|}{ Risk = South African market risk } & \multicolumn{3}{|c|}{ Risk = international market risk } \\
\hline & \multicolumn{2}{|c|}{ Annual return (\%) } & \multirow{2}{*}{$\begin{array}{l}\text { Increase in } \\
\text { return from } \\
\text { international } \\
\text { portfolio }\end{array}$} & \multicolumn{2}{|c|}{ Annual return (\%) } & \multirow{2}{*}{$\begin{array}{l}\text { Increase in } \\
\text { return from } \\
\text { international } \\
\text { portfolio }\end{array}$} \\
\hline & SA portfolio & $\begin{array}{c}\text { International } \\
\text { portfolio }\end{array}$ & & SA portfolio & $\begin{array}{c}\text { International } \\
\text { portfolio }\end{array}$ & \\
\hline 1969 & $-21,43$ & 24,86 & 46,29 & $-20,15$ & 23,81 & 43,96 \\
\hline 1970 & $-18,27$ & 6,97 & 25,24 & $-17,41$ & 6,04 & 23,45 \\
\hline 1971 & 5,04 & 24,17 & 19,13 & 4,70 & 23,10 & 18,40 \\
\hline 1972 & 36,86 & 33,53 & $-3,33$ & 30,21 & 31,26 & 1,05 \\
\hline 1973 & 27,50 & 26,26 & $-1,24$ & 24,35 & 25,60 & 1,25 \\
\hline 1974 & 34,66 & $-1,88$ & $-32,78$ & 32,17 & $-0,63$ & $-32,80$ \\
\hline 1975 & $-5,15$ & 15,48 & 20,63 & $-3,26$ & 13,32 & 16,58 \\
\hline 1976 & $-8,40$ & 24,34 & 32,74 & $-6,82$ & 21,85 & 28,67 \\
\hline 1977 & $-1,35$ & 3,27 & 4,62 & $-0,96$ & 2,64 & 3,60 \\
\hline 1978 & 34,38 & 21,43 & $-12,95$ & 30,46 & 19,67 & $-10,79$ \\
\hline 1979 & 41,80 & 26,70 & $-15,10$ & 34,14 & 24,53 & $-9,61$ \\
\hline 1980 & 70,47 & 19,56 & $-50,91$ & 62,23 & 17,57 & $-44,66$ \\
\hline 1981 & $-3,06$ & 14,38 & 17,44 & $-2,51$ & 12,79 & 15,30 \\
\hline 1982 & 12,66 & 18,87 & 6,21 & 10,64 & 16,39 & 5,75 \\
\hline 1983 & 40,12 & 32,66 & $-7,46$ & 34,53 & 29,89 & $-4,64$ \\
\hline \multicolumn{7}{|l|}{ Average \% } \\
\hline per year & 16,38 & 19,30 & 3,08 & 14,15 & 17,86 & 3,71 \\
\hline
\end{tabular}


returns of $17,86 \%$ and $19,30 \%$ at the international market risk level and the South African market risk level respectively.

A significant feature of the results in Table 1 is that the results fluctuate over a wide range. The South African portfolio has produced very erratic returns. An exceptionally high return of $70,47 \%$ was attained in 1980 and the lowest return of $-21,43 \%$ was obtained in 1969 (at the South African market risk). By contrast, the international portfolio produced fairly steady returns, with 1974 being the only year when slightly negative returns were obtained by this portfolio. These results demonstrate clearly the superior diversification properties of an international portfolio in comparison with a South African portfolio. Figure 1 highlights the relative performance of the two portfolios investigated.

Figure 1 clearly shows the relatively steady returns provided by the diversified international portfolio. Figure 1 also provides an answer to the question why the South African portfolio produced inferior returns on average, despite the very large positive returns in certain years. It can be seen that a South African portfolio outperformed the international portfolio by a wide margin in the years 1974, 1978, 1979, 1980 and 1983. However,

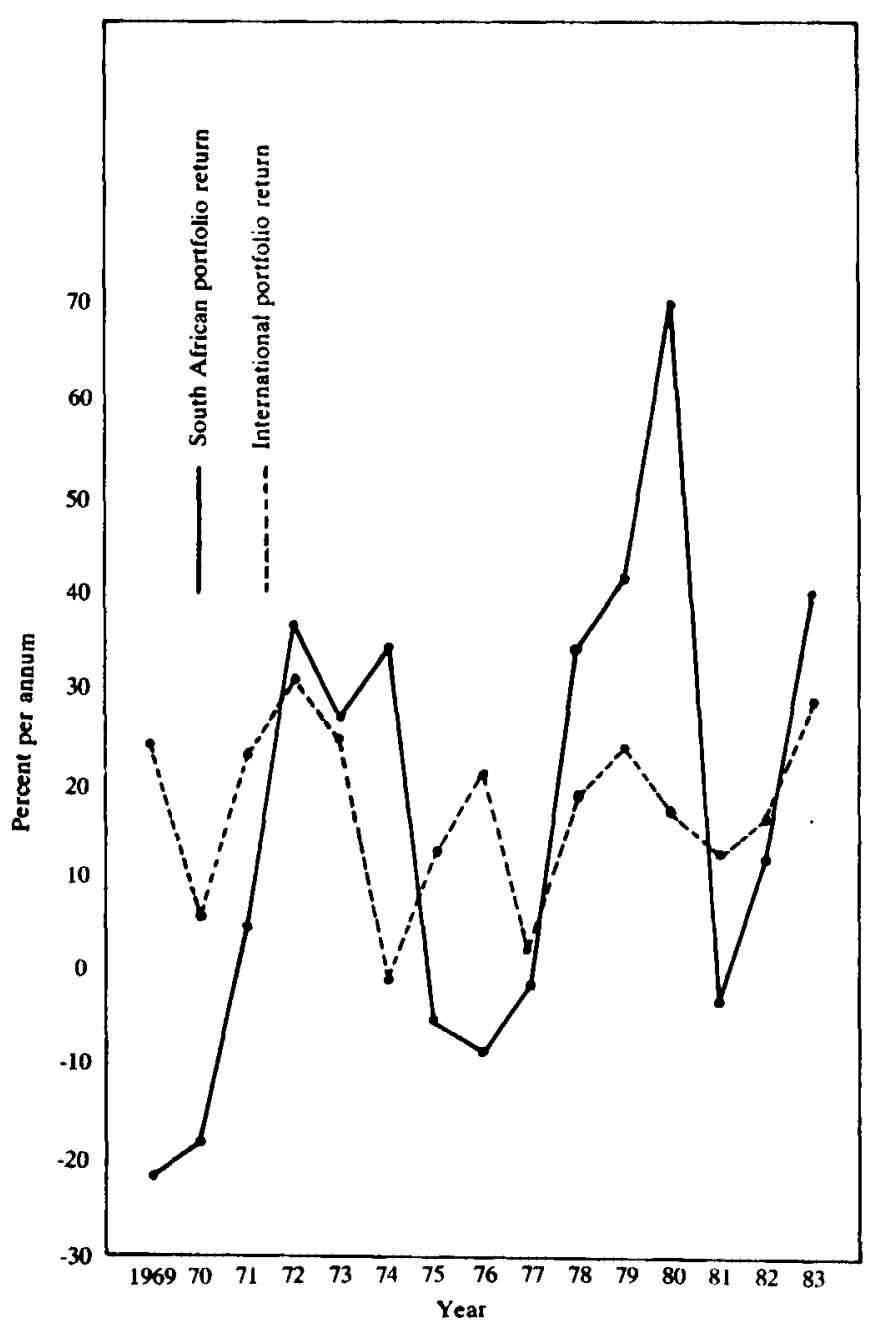

Figure 1 The distribution of annual returns of international and South African portfolios during 1969 - 1983. the South African portfolio produced large negative returns in the years 1969, 1970, 1975 and 1976. The high positive returns in certain years were insufficient to make up the large losses suffered in a number of years. These results indicate that the South African equities alone provided insufficient diversification to sustain a stable level of returns. By contrast, the international portfolio had no significant negative returns during the study period. Therefore, a collection of relatively smaller, but consistent, returns of the international portfolio was still able to outperform the South African portfolio which produced both large positive and negative returns. These results also demonstrate the ability of effective diversification to maximize the portfolio's longterm rate of return, even though many year-by-year returns may be less than the corresponding returns of riskier investments (Bernstein, 1983).

The results in Table 1 also show that an international portfolio which spreads the funds over the full range of securities available in equal amounts amongst the different investment categories would, on average, attain excess returns of $3,08 \%$ per annum in comparison with a South African portfolio which spreads the funds equally between goldming and industrial shares on the JSE. These comparisons were at the level of risk prevailing in the South African equity market during the study period. When a comparison is made at the risk level prevailing in the international equity market, the investor who purchased both South African and foreign equities attains an average annual gain of $3,71 \%$ over an investor that operates only on the JSE. Although these gains are large, they are significantly less than those attained by $e x$ post optimum portfolios (Bhana, 1986).

A limitation of the preceding discussion is that the annual returns from an international equity portfolio and an exclusively South African equity portfolio are measured at two different risk levels in each year. The measurement procedures do not consider the actual level of risk for each of the two portfolios. To overcome this deficiency, a standardized return (return adjusted for risk) is necessary for each portfolio. The average risk and return for the 15 years covering the $1969-1983$ period was calculated. The standardized return (return/ risk) was then calculated and is shown in Table 2.

From the results in Table 2 it can be seen that the ratio of international standardized return to the South African standardized return is 3,0387 . This suggests that the international portfolio has a relative performance which is 3,0387 times that of the South African portfolio when

Table 2 Standardized returns from South African and international portfolios chosen ex antefor the period 1969-1983.

\begin{tabular}{lccc}
\hline Portfolio & Average return & Average risk & Standardized retum \\
\hline $\begin{array}{c}\text { South African } \\
\text { portfolio }\end{array}$ & $16,38 \%$ & $26,56 \%$ & 0,6167 \\
$\begin{array}{c}\text { International } \\
\text { portfolio }\end{array}$ & $17,86 \%$ & $9,53 \%$ & 1,8740 \\
\hline
\end{tabular}


the actual risk associated with the two portfolios is taken into consideration. These results are supported by van den Honert (1984) who also showed that on the basis of standardized returns, international portfolios outperformed South African portfolios during the period $1969-1982$. Without taking into consideration the actual risks associated with the two portfolios, the South African portfolio compares favourably with the international portfolio. However, on the basis of riskadjusted performance, the international portfolio is shown to be far superior to its South African counterpart. Because of the erratic nature of the returns on South African equities (especially goldmining shares) a high level of risk is associated with local securities which perform poorly on a risk-adjusted basis. The substantially lower risks and higher growth rates attained in several foreign countries has contributed to the superior performance of the international portfolio.

An explanation of the superiority of the international portfolio can be found in the context of the prevailing exchange control regulations in South Africa. The pattern of returns on the JSE is characterized by the dominance of goldmining shares which comprise a substantial proportion of the total market capitalization. Historically, goldmining shares have provided similar returns to both South African investors (subject to exchange control) and foreign investors (holding diversified international portfolios), and the risk associated with these returns have been vastly different for these two groups of investors. A well-diversified international portfolio is able to diversify virtually the entire risk associated with South African goldmining shares. An international portfolio containing goldmining shares is able to attain relative high returns without adding to the overall portfolio risk. In contrast, a South African investor holding goldmining shares bears a large element of risk which is not diversifiable because of exchange control. These observations are supported by Carter (1983) who showed that goldmining shares are more efficient for overseas investors who are able to diversify away virtually the entire risk of investing in these shares while also yielding vastly superior returns.

The results of this study provide a strong case for international portfolio diversification by South African investors. Firstly, the ex post benefits from international portfolio investments are substantial and would justify the allocation of funds for foreign investments if exchange control regulations are abolished. It is unlikely that any South African investor will actually attain a point on the efficient frontiers constructed from ex post data. Investors will have to act ex ante and must make investment decisions before the year actually begins and cannot rely on the effect of events that have already taken place during the year. The results of the ex ante investment strategy show that as long as the investor is able to 'buy the market', substantial benefits are likely from international portfolios despite not being able to attain portfolios that lie on the efficient frontier.

A further argument in favour of international portfolio diversification by South African investors is the continuous politico-economic pressure against this country. Under this scenario it can be conjectured that the international value of South African currency has entered a phase of considerable uncertainty. The depreciation of the South African currency against the currencies of our major trading partners is likely to continue in the future. Therefore, the risk reduction possibilities for South African investors from international portfolios is likely to continue in the future. This view is supported by Barr (1986) who argues that volatile exchange rate movements are likely to result in South African-based international portfolios attaining even more dramatic returns, in Rand terms, in the future.

\section{Conclusion}

This investigation has focused attention on the likely benefits accruing to South African investors from foreign securities. The results of a naive ex ante investment strategy show that South African investors are likely to derive substantial benefits from international portfolio diversification. The results also suggest that investing in South African securities provided insufficient diversification to sustain a stable level of returns. By contrast the international portfolio would have provided investors with stable earnings during the entire 1969 - 1983 study period. Furthermore, the international portfolio was able to maximize the long-term rate of return, even though many year-by-year returns were less than the corresponding returns on South African securities. Khoury (1983) has shown that the perceived problems associated with investing in foreign securities are exaggerated and can easily be overcome by recent dzvelopments in international capital markets. This supports the hypothesis predicting the effectiveness of foreign security diversification from the standpoint of a South African investor (Bhana 1986).

The results of this investigation suggest that South African investors are bearing a high cost for the inability to attain effective diversification as a result of existing exchange control regulations. In view of the public policy implications of foreign security investments, representations should be made to the authorities with the objective of expediting exchange control reform in South Africa. Bhana (1985) reviewed the recommendations of the De Kock Commission of Inquiry and showed that the basic guidelines has been provided which will ultimately lead to the abolition of existing exchange control in South Africa. A gradual process of dismantling exchange control for residents is appropriate in view of the limited holding of foreign exchange reserves and the possible short-term disruptive effects of a complete abolition. Therefore, it is submitted that the authorities institute an orderly process of abolishing exchange controls in line with the strengthening of the domestic economy and favourable political developments.

\section{Acknowledgement}

Financial assistance rendered by the Human Sciences Research Council towards the cost of this research is hereby acknowledged. Opinions expressed or conclusions arrived at are those of the author and are not to 
be regarded as those of the Human Sciences Research Council.

\section{Roferences}

Barr, G.D.I. 1986. International diversification after 1985 the argument grows stronger. S. Afr.J. Bus. Mgmnt., vol.17, $139-142$.

Bernstein, P.L. 1983. Winning big by playing it safe. Institutional Investor, January, 241-246.

Bhana, N. 1985. The recommendations of the De Kock Commission of Inquiry and its implications for foreign security investments by South African residents. S.Af.J.Bus.Mgmnt., vol. 16, 204-208.

Bhana, N. 1986. International share portfolio diversification: powsible benefits for South African investors.
S.Afr.J.Bus.Mgmnt., vol. 17, 162-168.

Carter, K.J. 1983. The estimation of security Beta Coefficients on the Johannesburg Stock Exchange. Unpublished Ph.D. thesis, University of Cape Town.

Grubel, H. 1968. Internationally Dtversified Portfolios: Welfare Gains and Capital Flows. Am.Econ.Rev., vol. 58, $1299-1314$.

Khoury, S.J. 1983. Investment Management - Theory and Application. New York: Macmillan Publishing Company Inc., 674p.

Solnik, B. \& Noetzlin, B. 1982. Optimal international asset allocation. J.Portfolio Mgmnt., vol.9, fall, 11-21.

Van den Honert, R.C. 1984. A Mathematical Approach to the Evaluation of International Diversification for the South African Investor. Unpublished M.Sc. thesis, University of Cape Town. 